\title{
The impact of potential Brexit scenarios on German car exports to the UK: an application of the gravity model
}

\author{
Jacqueline Karlsson, Helena Melin and Kevin Cullinane ${ }^{*}$ (D)
}

\author{
* Correspondence: \\ kevin.cullinane@gu.se \\ School of Business, Economics and \\ Law, University of Gothenburg, PO \\ BOX 610, SE-405 30 Gothenburg, \\ Sweden
}

\begin{abstract}
The objective is to forecast the impact of potential Brexit scenarios on the export volume of passenger cars from Germany to the UK. Based on Germany's total export volume of passenger cars, a double-logarithmic gravity model is specified and estimated using Ordinary Least Squares (OLS) regression. The final estimated model has strong explanatory power, with all variables significant at the $5 \%$ level. This is used for forecasting future export volumes under different Brexit scenarios. Diagnostic tests suggest that the model is robust and efficient. All tested Brexit scenarios are found to negatively impact passenger cars export volumes from Germany to the UK. The level of tariffs is found to have the most significant effect, but lower GDP due to Brexit is forecast to offset the benefits of trading with lower tariffs. The most pessimistic scenario for 2030 forecasts is a reduction of 15.4\% compared to the 'no Brexit' base-case scenario.

Keywords: Automotive industry, Cars, Brexit, Gravity model, Trade, Forecasts
\end{abstract}

\section{Introduction}

The UK held a referendum on continued membership of the EU on June 23rd 2016. The 'Leave Campaign' won a surprising victory, meaning that what is commonly referred to as Brexit (Hunt and Wheeler 2017) has emerged as an imminent reality. Subsequently, the UK Government has formally invoked Article 50 of the Lisbon treaty of the EU on March 30th 2017, thus starting a two-year process of leaving the EU (Castle 2017).

Despite the fact that Brexit is a relatively new phenomenon, the literature already contains works on the overall Brexit and referendum (Butler et al. 2016; Glencross 2015; Menon and Salter 2016a; Hobolt 2016; Vasilopoulou 2016), the reasons behind Brexit (Menon and Salter 2016b; Thielemann and Schade 2016), the referendum outcome (Goodwin and Heath 2016), the negotiations or legal implications following it (Jensen and Snaith 2016; Lazowski 2016; Kroll and Leuffen 2016; Gordon 2016; Chalmers 2016), the future challenges for the EU (Biscop 2016; Simón 2015) and, even, estimates of the financial implications (Boulanger and Philippidis 2015).

Authoritative sources suggest that there are three long-term scenarios that could potentially emerge as outcomes from the UK's Brexit negotiations with the EU (HM Treasury 2016; PwC 2016; European Union Committee 2016):

(C) The Author(s). 2018 Open Access This article is distributed under the terms of the Creative Commons Attribution 4.0 International License (http://creativecommons.org/licenses/by/4.0/), which permits unrestricted use, distribution, and reproduction in any medium, provided you give appropriate credit to the original author(s) and the source, provide a link to the Creative Commons license, and indicate if changes were made. 
- UK becomes a member of the EEA; with EU non-member states treated as members of the Single Market as though they were part of the EU (European Union Committee 2016). As such, this would mean that the free movement of goods, capital, services and people would continue and would be legally enforced by designated institutions under the ultimate jurisdiction of the EU Court of Justice. The UK, however, would not be a part of the customs union. This would enable the UK to independently and separately sign FTAs with trading partners other than the EU (Emerson 2016). A non-member country must, however, pay into the EU budget. Despite the fact that the UK would not be allowed to take part in future decision making processes within the EU (Emerson 2016), members of the EEA are required to contribute funds to decrease social and economic disparities; a form of grant to poorer EU members based on the contributor's economic situation (HM Treasury 2016). To put this financial obligation into context, in 2011, the UK's net contribution to the EU amounted to GBP 128 per capita while, as a member of the EEA, that of Norway amounted to GBP 108 per capita (House of Commons 2013). Traditionally, this type of agreement has suited smaller countries such as Norway, Iceland and Liechtenstein (OECD 2016).

- UK negotiates a bilateral trade agreement with the EU; This could reduce most tariff and non-tariff barriers on goods traded, but agreements that yield the greatest access to the Single Market usually come with the greatest obligations, particularly with respect to the EU's four freedoms that are deemed indispensable (HM Treasury 2016; Economist 2016).

- UK trades with the EU under WTO terms; This is the most likely scenario if no other agreement is reached between the parties (Economist 2017), particularly since the British Government has already committed to not accepting any deal that is not in the UK's best interests (Parker and Barker 2017). The WTO standards are based on the concept of the Most Favoured Nation (hereinafter MFN), whereby all countries have to be treated equally and countries cannot discriminate between trading partners. Hence, if one country would like to change the tariff for one of its trading partners, it has to change it for all other trading partners as well (World Trade Organization 2017a). The main advantage of this option is that it would free the UK from all obligations associated with access to the Single Market (HM Treasury 2016). However, the tariffs on some goods could be high.

All three of these scenarios would result in different tariffs on goods and services and all are predicted to have a significant impact on the UK's GDP (OECD 2016). Through the fundamental changes in the nature of its trading relationships with EU partners that any of these three scenarios will bring about, the GDPs of the UK's current trading partners within the EU are also potentially under threat. In relation to this potential, some attempts have been made to quantify the potential impact of Brexit within particular sectors or industries. Examples include the marine environment (Boyes and Elliott 2016), the agriculture or food sector (Swinbank 2016; Grant 2016; Matthews 2016) and the pharmaceutical industry (Song 2016; Baker et al. 2016). Similarly, the focus of the work presented herein is the automotive sector and, more specifically, the fundamental objective is to assess the potential impact of Brexit on the volume of passenger cars exported from Germany to the U.K. 
Germany is one of the UK's most important trade partners, ${ }^{1}$ with its main export to the UK being passenger cars. The German automotive industry is the biggest car industry in the EU, producing $34.9 \%$ of the total number of cars produced in the EU (OICA 2017). Approximately $2 \%$ of Germany's total population works in direct automotive manufacturing, compared to the EU average of $1 \%$ and the equivalent value of $0.5 \%$ in the UK (ACEA 2016). The figure for Germany equates to about 500,000 permanent employees (VDA 2017).

In $2015,77 \%$ of all passenger cars manufactured in Germany were sold abroad (VDA 2017), representing a total export volume of 7.8 million passenger cars. Out of this total, 1.4 million passenger cars were exported to the $\mathrm{UK}^{2}$ (United Nations 2017a). This equates to the fact that $39 \%$ of the total number of imported units into the UK were of German origin $^{3}$ (United Nations 2017a). The four most important German car manufacturers in terms of volume are Volkswagen, BMW Group, Mercedes-Benz and Audi, with BMW and Volkswagen having the largest market shares ${ }^{4}$ (Stastista, 2017), with the most popular models being the Volkswagen Golf, Volkswagen Polo, Audi A3 and Mini. In 2016, the combined sales of these models were 223,038 units, representing $32,3 \%$ of the sales of the top ten most popular models sold in the UK (SMMT 2017).

As the result of global trends in production and consumption, the automotive industry has come to be characterised by a globalised supply base, where there has been an increased amount of outsourcing to suppliers. Another trend has been to adopt Just-in-time concepts (Thomas and Oliver 1991). Both these phenomena have combined to leave automotive manufacturers more and more dependent on their suppliers. Indeed, several companies have gone so far as to pursue even more interactive relationships with their suppliers, with collaboration in product development, supplier development, information sharing and more (McIvor et al. 1998). As a consequence, automotive supply chains are both highly interconnected and international and consist of many suppliers. This makes the industry particularly vulnerable to the imposition of tariffs and, within the context of the EU, highly reliant on the Single Market (Campbell 2016). If tariffs were to be applied within this context, the additional time required for customs checks would be significant and the increase in cost substantial (Campbell 2016; Monaghan 2016). In addition, as O'Grady (2016) suggests, the imposition of tariffs in the automotive industry would be administratively difficult.

The sheer volume of German passenger car exports to the UK and the complexity of the sector's supply chain network, as well as the significance of the trade for both the German and UK economies, more than justifies a focus on the sector when considering the three scenarios likely to emerge from Brexit negotiations. This work applies the gravity model as a reduced form of general equilibrium model of international trade in final goods. The estimated version of the model provides the foundation for a quantitative forecasting model that will facilitate achieving the objective of forecasting the impact of the three likely Brexit scenarios on Germany's passenger car exports to the UK.

The remainder of the work is structured as follows. The chosen methodology is justified and described in the following section. Details of the analysis which leads to an estimated version of the model are provided in section "Model estimation". This includes the systematic elimination of variables and the application of diagnostic tests. Section "Results" outlines the results achieved from applying the forecasting model. Finally, in section "Conclusions", conclusions are drawn and suggestions made for future research. 


\section{Methodology}

\section{The gravity model}

The gravity model is commonly applied in economics and has been deemed to be a successful tool for estimating international trade (Anderson 1979), a general framework to examine trade patterns (Eichengreen and Irwin 1995) and one of the most "empirically successful" trade analytical tools in economics (Anderson and van Wincoop 2003, p.170). The theoretical foundation of the model has been established through the work of several scholars, such as Linnemann (1966); Bergstrand (1985); Evenett and Keller (2002) and Anderson and van Wincoop (2003).

The gravity model estimates bilateral trade flows where trade is positively related to the level of GDP of the trading partners and negatively related to the distance between them. In the model, bilateral trade flows are based on the mutual gravitational force between the nations, with the gravity variable GDP reflecting mass. In addition to the conventional standard version of the model, several modifications can be made and dummy variables added (Chi and Kilduff 2010).

The gravity model has been widely used to estimate product and factor movements within the context of bilateral trade flows across international borders (Anderson 1979; Bergstrand 1985; McCallum 1995; Baier and Bergstrand 2001; Hummels 2001; Feenstra 2002; Anderson and van Wincoop 2003; Anderson and van Wincoop 2004; Anderson 2011) and trade agreements (McCallum 1995; Lavergne 2004; Rose 2004; Carrere 2006; Baier and Bergstrand 2007; Caporale et al. 2009; Cipollina and Salvatici 2010; Kepaptsoglou et al. 2010). Nobel laureate, Jan Tinbergen, was the first to apply the gravity model to the effect of Free Trade Agreements (FTAs) on bilateral trade flows, by including them in the model as a dummy variable (Tinbergen 1962). Since then, the gravity model has become the foundation for estimating the effects of FTAs and customs unions on bilateral trade flows (Bayoumi and Eichengreen 1995), particularly in relation to bilateral trade flows between fellow members of the EU (Balassa 1967; Aitken 1973; Abrams 1980; Brada and Mendez 1985; Frankel et al. 1995).

There is minimal agreement as to which variables should be included in the gravity equation, and which ones that should be omitted (Yamarik and Ghosh 2005). Anderson and van Wincoop (2003) point out that bias can appear in both the estimation and the analysis through the omission of the wrong variables. However, trade data appears to perform empirically well in the gravity model (Feenstra 2002) and, as a result, the gravity model has gained in popularity in the empirical trade literature (Yamarik and Ghosh 2005).

The gravity equation is derived as a reduced form from a general equilibrium model of international trade in final goods. According to Chi and Kilduff (2010) the original gravity model in international trade is defined as:

$$
T_{i j}=A \times\left(\frac{Y_{i} \times Y_{j}}{D_{i j}}\right)
$$

...where the variables are defined as follows:

$T_{i j}$ trade flow from country $i$ to country $j$;

$Y_{i}$ GDP of country $i$;

$Y_{j}$ GDP of country $j$;

$D_{i j}$ physical distance between country $i$ and country $j$ and; 
A is a constant.

Nevertheless, according to Bergstrand (1985), the gravity model in international trade commonly takes the form:

$$
T_{i j}=\beta_{0}\left(Y_{i}\right)^{\beta_{1}}\left(Y_{j}\right)^{\beta_{2}}\left(D_{i j}\right)^{\beta_{3}}\left(A_{i j}\right)^{\beta_{4}} \mu_{i j}
$$

...where the parameters to be estimated are denoted by $\beta$ and the variables are defined as follows:

$T_{i j}$ trade flow from country $i$ to country $j$;

$Y_{i}$ GDP of country $i$;

$Y_{j}$ GDP of country $j$;

$D_{i j}$ physical distance between country $i$ and country $j$;

$A_{i j}$ other factor(s) either aiding or resisting trade between country $i$ and country $j$ and;

$\mu_{i j}$ a logarithmic-normally distributed error term with $\mathrm{E}\left(\ln \mu_{i j}\right)=0$.

The gravity equation is normally specified in a double-logarithmic form and estimated using Ordinary Least Squares (OLS) regression analysis (Eichengreen and Irwin 1995), although there are some exceptions to this general practice. Variations which have been applied to resolve a number of different issues include the use of non-linear OLS (Anderson and van Wincoop 2003), maximum likelihood estimation (Baier and Bergstrand 2007), a tobit model form (Chen 2004; Martin and Pham 2015), poisson pseudo maximum-likelihood estimation (Santos Silva and Tenreyro 2006) and a semi-logarithmic form (Eichengreen and Irwin 1995).

\section{Sample}

The sample used to estimate the model consisted of all countries to which Germany exported more than 1000 passenger cars in the designated year and for which data were available. Country $i$ in the model denotes Germany and country $j$ the import country. The total sample consists of more than 80 observations per year, representing approximately $98 \%$ of the total quantity of passenger cars exported by Germany over the 4-year period 2012 to 2015 inclusive. $^{5}$

In specifying the sample, the work was delimited by focussing solely on the export of complete cars. Thus, interactions between countries or industries which take place either before or after a complete car is exported are not accounted for. This means that the following are not addressed in the sample specification, data collection, model estimation or forecasts: the movement of components; whether Brexit scenarios bring about a change in the export quantities of passenger cars from Germany to other countries or; from where the UK would import cars in the future in the case that export quantities from Germany are predicted to decline. Model forecasts assume ceteris paribus applies to external factors. Thus, for example, they do not take into account the expected growth in demand for electric cars which, inevitably, will disrupt the current market structure. Finally, the work does not distinguish between new and used passenger cars.

\section{Selection of variables and data collection}

The dependent variable in the model is the volume of passenger cars exported from Germany (country $i$ ) to a range of importing nations (country j). Data on the export and import quantities of passenger cars from country $i$ to country $j$ were collected from 
the Comtrade database ${ }^{6}$ (United Nations 2017a). The collection of the required trade data was undertaken on the basis of the following approach:

- Data were extracted using the 4th version of the Harmonized Commodity Description and Coding System (hereinafter HS) which is an international nomenclature. The six-digit system consists of goods classified at different levels of specificity.

- Some countries do not report data at lower commodity code levels (United Nations Statistics 2017a). Hence, this analysis uses the highest commodity code level for which quantity is reported. Thus, the commodity code "HS 8703 Passenger Cars" is used to collect data on imported and exported quantities of passenger cars.

- Although the Comtrade database provides information on quantity, weight and value of trade, this analysis utilises quantities so that issues such as valuation and currency conversion are avoided.

- In line with the advice of United Nations Statistics (2017a), the total quantities were based on the consolidated amount for all countries and not what the database refers to as "world" totals.

- An average was taken for those situations where there were differences between reported export and reported import quantities (United Nations Statistics 2017b).

- Where relevant, export quantities include re-exports.

The core of the gravity model is based on GDP and distance, but a variety of variables were considered for initial inclusion (Yamarik and Ghosh 2005). Selecting the appropriate variables for inclusion is important since including irrelevant variables can lower the precision of the model, while omitting variables that are important could introduce bias into the model estimates (Greene 2003).

The independent variables included within the initial specification of the gravity model to be tested are as follows: the GDP of countries $i$ and $j$; the GDP per capita of countries $i$ and $j$; the population of countries $i$ and $j$; the geographical distance between the trade partners; the quality of logistics in country $j$ and; the import tariff on passenger cars moving from country $i$ to country $j$. In addition to these, the gravity model is initially specified to include a number of dummy variables controlling for: membership of the EEA; if country $j$ has direct access to the sea; country adjacency and; if countries $i$ and $j$ share a common language. The choice of these variables was made by reviewing work by, for example, Aitken (1973), Rose (2004) and Chi and Kilduff (2010), who have all performed similar studies.

\section{GDP and population}

GDP is included in the model on the basis that the GDP of an exporting nation measures its productive capacity (Aitken 1973: Abrams 1980), while the GDP of an importing nation provides a measure of absorptive capacity or potential market size (Tinbergen 1962). Together with population, the value of GDP will impact the demand for imports (Aitken 1973; Abrams 1980). In terms of the exporting nation, the potential for economies of scale suggests that the larger the population, the more efficient is market production (Aitken 1973).

GDP per capita for countries $i$ and $j$ are also included in the model because, as established by Linder (1961), countries that have similar demand structures trade more with 
each other than dissimilar countries and that greater inequality has a negative effect on trade. Bergstrand (1990) argues that this relationship is present in both the supply structure, based on the Heckscher-Ohlin theorem, as well as in the demand structure, such as in the work by Linder (1961).

Data on GDP, population and GDP per capita for all countries were collected from the World Bank (2017a). GDP data referred to the GDP at purchaser's prices in USD ${ }^{7}$; population data was the total population based on mid-year figures for all residents, regardless of legal status or citizenship and; GDP per capita is the ratio of the former over the latter (World Bank 2017a). In utilising this source, it should be recognised that the World Bank relies on international and regional sources such as the United Nations (2017b), Eurostat by the European Commission (2017) and Prism (2017). The World Bank also uses national statistics gathered from census reports and other national sources which mean that they are reliant on those individual countries to provide updated statistics (see World Bank (2017a) for more details). Countries which did not report their national statistics were excluded from the sample.

\section{Distance, Total logistics cost and the quality of logistics}

Geographical distance has long been treated as a proxy for transportation cost (for example, see Linnemann 1966). Disdier and Head (2008) found that bilateral trade is almost directly inversely proportionate to physical distance, with an average increase of distance by $10 \%$ reducing the trade between the parties by approximately $9 \%$. Chi and Kilduff (2010) suggest that this is because transportation costs and convenience favour closer relationships and sourcing. Due to the advancement of logistics-related technology, distance as a proxy for transportation costs has been questioned and total logistics costs argued as being a more appropriate input variable. Disdier and Head (2008) have shown, however, that the effect of geographical distance has not declined in more recent years, indicating that technological change has not led to a reduction in the impact of distance.

A distance variable is thus included within the model as one proxy for total logistics cost, with distance measured either from the capital city of country $i$ to the capital city of country $j$, as suggested by Yamarik and Gosh (2005) or as the "great circle distance" from the location where the largest port is situated in country $i$ to the location of the largest port of country $j$, in line with Smarzynska (2001). The choice between these two measures is made on a country-by-country basis where countries north of Turkey or located within Europe were assumed to transport cars by land and the others by sea. If country $j$ lacked a port and was assumed to transport cars by sea, the distance was measured from the capital city of country $j$ to the closest port, and from that port to the largest port of country $i$. Road transport distances were obtained from Google Maps (2017) and sea transport distances from Marinetraffic (2017). ${ }^{8}$

In order to test other potential influences on total logistics cost, the model initially included a proxy for infrastructure, namely the total span of the motorway network, in line with Bougheas et al. (1999). However, due to the characteristics of the international car trade (i.e. it is mostly moved as seaborne freight in car carriers), the model was later modified to instead include a dummy variable for country j's direct access to the sea. Google Maps (2017) provided the source for data on whether country $j$ had direct access to the sea and for countries that share a border with country $i$. 
The overall quality of a nation's logistics system is sourced from the World Bank (2017b), where the Logistics Performance Index (LPI) is derived from a survey where respondents rate countries based on several logistics performance criteria: "the efficiency of customs and border clearance"; "the quality of trade and transport infrastructure"; "the ease of arranging competitively priced shipments"; "the competence and quality of logistics services"; "the ability to track and trace consignments" and; "the frequency of which shipments reach consignees within scheduled or expected delivery times" (World Bank 2014, pp.51-52). The index is only made available every second year. Hence, the index for 2012 was applied to the models for 2012 and 2013 and the index for 2014 was applied in 2014 and 2015. The input variable was based on the country with the highest index value being the benchmark and determined as follows for the importing nation, country $j$ :

$$
\text { LOGIS }_{j}=\left(\frac{x_{j}}{x_{i}}\right) \times 100
$$

...where:

$L_{\text {LGIS }}$ represents the overall quality of logistics performance of country $j$ in year $t ; x_{j}$ is the observed quality of logistics in country $j$ in year $t$ and; $x_{i}$ is the observed quality of logistics in the country with the highest LPI value in year $t$.

\section{Tariffs}

All countries profit from less barriers to trade (Eaton and Kortum 2002) and reductions of tariffs have been argued to explain about $26 \%$ of the growth of trade in OECD countries between the late 1950s and the late 1980s (Baier and Bergstrand 2001). Therefore, a variable reflecting the tariff rate was included in the model. For the purpose of collecting the data, the MFN tariff rates for 'HS 8703 Passenger Cars' were sourced from the World Trade Organization (2017b). The rates were presented as applied MFN tariff rates in weighted averages based on the sub-categories of 'HS 128703 Passenger Cars'. The data were compared to all of the EU's PTAs and. if there was a deviation, the bound rate in the PTA was applied. In cases where HS 8703 was not specifically referred to in a PTA, the applied MFN tariff rate presented by the World Trade Organization (2017b) was utilised.

In addition, the most recent updated tariff rates were assumed to be valid in the years following. Thus, if country $j$ reported a tariff rate $x$ for HS 8703 in year $t$, then this rate was applied in years $t+1$ and $t-1$ in cases where there was no other tariff rate present. If there was a change of tariff rate $x$ to tariff rate $z$ in year $t+1$, the tariff rate $z$ was applied in $t+1$ and all years following it. If the tariff rate $x$ was introduced and came into effect in year $t-1$, but tariff rate $y$ was applied in all years before year $t-1$, then the tariff rate $x$ applies in year $t-1$ and all years following it. A value of 1 was added to all tariff rates so that logarithms could be applied.

\section{Language commonality and country adjacency}

Language commonality was included to show whether countries $i$ and $j$ shared a language or cultural similarity (Frankel et al. 1995) since this makes trade easier (Bougheas et al. 1999). When two countries share a language, it increases trade "substantially" (Havrylyshyn and Pritchett 1991, p.6). In addition to the language 
commonality variable, the model also included a border effect dummy variable. Aitken (1973, p.882) argues that neighbouring countries can be expected to trade more with each other due to "similarity of tastes and an awareness of common interests". The data on language commonality was based on CIA (2017).

\section{EEA membership}

Most economists argue that international trade should be free (Rose 2004). However, the regional integration provided by the $\mathrm{EU}$ has the "potential to harm participants through trade diversion or nonparticipants nearby through worsened terms of trade" (Eaton and Kortum 2002, p.1743). A dummy variable is included, therefore, for membership of the European Community. Baier and Bergstrand (2001) explain that it might seem unnecessary to include dummy variables to reflect a preferential trade agreement (hereinafter PTA), but the PTA itself might lead to greater trade beyond the effect of no tariff barriers. Input data on membership of the EEA was collected from the European Union (2017) and included all member countries of the EU or EFTA.

\section{Model specification}

In summary, the fully specified as follows:

$$
\begin{gathered}
\ln \left(E X_{i j}\right)=\alpha+\beta_{1} \ln \left(G D P_{i}\right)+\beta_{2} \ln \left(G D P_{j}\right)+\beta_{3} \ln \left(D_{i j}\right)+\beta_{4} \ln \left(P O P_{i}\right) \\
+\beta_{5} \ln \left(P_{j}\right)+\beta_{6} \ln \left(G D P C A P_{i}\right)+\beta_{7} \ln \left(G D P C A P_{j}\right) \\
+\beta_{8} \ln \left(\text { TARIFF }_{i j}\right)+\beta_{9} \ln \left(L O G I S_{j}\right)+\beta_{10} C A_{i j} \\
+\beta_{11} L C_{i j}+\beta_{12} E E A_{j}+\beta_{13} S E A_{j}+e_{i j}
\end{gathered}
$$

..where the parameters to be estimated are denoted by $\beta$ and the variables defined as follows:

$E X_{i j}$ export of passenger cars from country $i$ to country $j$, in units;

$G D P_{i}$ GDP of country $i$, in current USD;

$G D P_{j}$ GDP of country $j$, in current USD;

$D_{i j}$ physical distance between the trade centre in country $i$ and country $j$, in kilometres;

$P O P_{i}$ total population of country $i$;

$P O P_{j}$ total population of country $j$;

GDPCAP $P_{i}$ GDP per capita of country $i$, in current USD;

$G D P C A P_{j}$ GDP per capita of country $j$, in current USD;

TARIFF $_{i j}$ tariff rate that country $j$ imposes on passenger cars from country $i$;

LOGIS quality of logistics of country $j$;

$C A_{i j}$ country adjacency, a dummy variable with a value of 1 if country $j$ shares a common border with country $i, 0$ otherwise;

$L C_{i j}$ common language, a dummy variable with a value of 1 if country $j$ shares an official language with country $i, 0$ otherwise;

$E E A_{j}$ European Community, a dummy variable with a value of 1 if country $j$ is a member of the European Community, 0 otherwise;

$S E A_{j}$ direct access to the sea, a dummy variable with a value of 1 if country $j$ has direct access to the sea, 0 otherwise; and.

$e_{i j}$ the error term. 
This model is estimated using OLS regression analysis. A higher GDP and population in country $j$ were expected to lead to greater demand and, consequently. to higher passenger car exports from country $i$ to country $j$. A higher GDP and population in country $i$ were expected to increase the production capacity. Similarly, a higher quality of logistics in the importing country can also be expected to be positively related to trade volumes. With respect to the dummy variables, the adjacency of trading nations, a common language, membership of the EEA and direct access to the sea would all also be expected to facilitate trade. Hence, the variables GDP $;$ POP $P_{j}$ GDPCAP $P_{j} L O G I S_{j} ; C A_{i j} ; L C_{i j} E E A_{j}$ and $S E A_{j}$ were all expected to be positively correlated to export quantities. On the other hand, increasing physical distance between trade partners, as well as higher tariffs, were both expected to have a depressing effect on trade quantities. Hence, the variables $D_{i j}$ and Tariff $i j$ were expected to be negatively correlated to trade volumes.

\section{Model estimation}

\section{Systematic elimination of variables}

An econometric problem can occur when the dependent variable is a component of one of the regressors or, more generally, when the regressors in the model are correlated with the disturbance term (McCallum 1995). The dependent variable, i.e. the export volume of passenger cars from country $i$ to country $j$, is a component of the GDP of country $i$ and, consequently, the latter variable was removed. Similarly, GDP per capita and population for country $i$ were also removed, since they were also strongly correlated with GDP. The results of the regressions with the remaining variables are displayed in Table 1. In line with the approach presented by Yamarik and Ghosh (2005), variables were added or removed from the regression equation on a one-by-one basis to determine how they might affect the final regression equation.

As shown in Table 1, the dummy variables representing direct access to the sea and EEA membership were excluded from the model, due to their low impact on the overall explanatory power of the regression; almost all countries in the dataset had access to the sea. Moreover, the dummy variable EEA was also removed, since it was strongly correlated with distance and tariffs, suggesting that the trade-creating benefits of EEA membership are captured by other regressors. The two remaining dummy variables common language and country adjacency - were also excluded, since they were statistically insignificant. Lastly, the population of country $j$ was removed due its low overall impact on the model.

After conducting the systematic elimination, the remaining independent variables were: GDP of country $j$; geographical distance between country $i$ and country $j$; import tariffs and; the quality of logistics of country $j$. A value of 1 was added to the variable TARIFF $_{i j}$ so that logarithms could be applied. The variable LOGIS $j$ was based on the country with the highest index value as defined in Eq. (4).

The final gravity model, as shown at step (6) in Table 1, is defined as:

$$
\begin{aligned}
& \ln \left(E X_{i j}\right)=\alpha+0,760 \ln \left(G D P_{j}\right)-0,369 \ln \left(D_{i j}\right) \\
& -3,958 \ln \left(\text { TARIFF }_{i j}\right)+1,988 \ln \left(\text { LOGIS }_{j}\right)+e_{i j}
\end{aligned}
$$

Or, more specifically: 
Table 1 Systematic elimination of variables

\begin{tabular}{|c|c|c|c|c|c|c|}
\hline & $(1)$ & $(2)$ & (3) & (4) & $(5)$ & (6) \\
\hline \multirow[t]{2}{*}{$\mathrm{GDP}_{\mathrm{j}}$} & 0,676 & 0,681 & 0,667 & 0,675 & 0,677 & 0,760 \\
\hline & $(3.58)$ & $(3.68)$ & (3.69) & $(3.75)$ & (3.78) & $(12.46)$ \\
\hline \multirow[t]{2}{*}{ Distance $_{i j}$} & $-0,376$ & $-0,371$ & $-0,311$ & $-0,329$ & $-0,361$ & $-0,369$ \\
\hline & $(-3.19)$ & $(-3.25)$ & $(-3.11)$ & $(-3.36)$ & $(-5.47)$ & $(-5.86)$ \\
\hline \multirow[t]{2}{*}{ Tariff $_{\mathrm{ij}}$} & -4182 & -4189 & -4321 & -4263 & -4230 & -3958 \\
\hline & $(-4.24)$ & $(-4.27)$ & $(-4.45)$ & $(-4.46)$ & $(-4.47)$ & $(-4.59)$ \\
\hline \multirow[t]{2}{*}{ Logistics $_{j}$} & 2261 & 2247 & 2154 & 2194 & 2266 & 1988 \\
\hline & $(2.72)$ & $(2.74)$ & $(2.69)$ & $(2.76)$ & $(2.91)$ & $(4.42)$ \\
\hline \multirow[t]{2}{*}{ Population $_{j}$} & 0,085 & 0,083 & 0,095 & 0,086 & 0,081 & \\
\hline & $(0.53)$ & $(0.53)$ & $(0.61)$ & $(0.55)$ & $(0.53)$ & \\
\hline \multirow[t]{2}{*}{$\mathrm{EEA}_{j}$} & 0,079 & 0,087 & 0,119 & 0,111 & & \\
\hline & $(0.33)$ & $(0.37)$ & $(0.51)$ & $(0.48)$ & & \\
\hline \multirow[t]{2}{*}{ Common language $_{\mathrm{ij}}$} & 0,636 & 0,614 & 0,362 & & & \\
\hline & $(4.71)$ & $(4.65)$ & $(2.50)$ & & & \\
\hline \multirow[t]{2}{*}{ Country adjacency $_{i j}$} & $-0,392$ & $-0,401$ & & & & \\
\hline & $(1.77)$ & $(1.83)$ & & & & \\
\hline \multirow[t]{2}{*}{ Direct access to the sea ${ }_{j}$} & 0,058 & & & & & \\
\hline & $(0.43)$ & & & & & \\
\hline Observations & 84 & 84 & 84 & 84 & 84 & 84 \\
\hline - of total export quantity & 0,981 & 0,981 & 0,981 & 0,981 & 0,981 & 0,981 \\
\hline Significance F & 0,000 & 0,000 & 0,000 & 0,000 & 0,000 & 0,000 \\
\hline R Square & 0,866 & 0,866 & 0,864 & 0,863 & 0,862 & 0,862 \\
\hline Adjusted R Square & 0,849 & 0,851 & 0,851 & 0,852 & 0,854 & 0,855 \\
\hline
\end{tabular}

Note: t-statistics are displayed in parentheses

$$
\begin{aligned}
\ln \left(E X_{i j}\right) & =\alpha+0,760 \ln \left(G D P_{j}\right)-0,369 \ln \left(D_{i j}\right)-3,958 \ln \left(\text { TARIFF }_{i j}+1\right) \\
& +1,988 \ln \left(\left(\frac{x_{j}}{x_{i}}\right) \times 100\right)+e_{i j}
\end{aligned}
$$

...where the variables are defined as follows:

$E X_{i j}$ Export of passenger cars from country $i$ to country $j$, in units;

$G D P_{j}$ GDP of country $j$, in current USD;

$D_{i j}$ Physical distance between the trade centres in country $i$ and country $j$, in kilometres;

$T_{A R I F F_{i j}}$ Tariff rate that country $j$ imposes on passenger cars from country $i$; and.

LOGIS $_{j}$ Quality of logistics of country $j$.

A confidence interval of $95 \%$ was used to test the model. All variables were statistically significant, the results were consistent over several years and contributed to the overall explanatory power of the model. Hence, the variables were considered robust and efficient in measuring the impact of Brexit on German car exports to the U.K.

\section{Diagnostic testing}

The final estimated gravity model, as arrived at through systematic elimination and expressed in Eq. (6), was further analysed with respect to the assumptions which underpin the OLS regression technique utilised (Montgomery et al. 2012). 
The relationship between the dependent variable and the regressors was tested using scatter diagrams and a correlation matrix (Wegman 1990) All covariates in the final equation were found to have an approximately linear relationship with the dependent variable, although a few outliers were present. Table 2 presents the Pearson's correlation for 2015 for all variables included in the final analysis.

The presence of multi-collinearity is tested for using the Variance Inflation Factor (hereinafter VIF) as suggested by O'Brien (2007) and Montgomery et al. (2012). The VIF is defined as:

$$
V I F_{k}=\frac{1}{\left(1-R_{k}^{2}\right)}
$$

...where $\mathrm{VIF}_{\mathrm{k}}$ is the Variance Inflation Factor for the estimated coefficient $k$ and $\mathrm{R}_{\mathrm{k}}$ is the coefficient of multiple determination of the estimated coefficient $k$. According to O'Brien (2007), the estimated value of a coefficient is seriously affected by multi-collinearity if the value of the VIF is greater than 10. As shown in Table 3, the calculated VIF for all coefficients, for all years tested, have values lower than 3 . This provides quite strong evidence that multi-collinearity is not present within the dataset.

A Q-Q plot (Liang et al. 2004) suggests that the normality assumption is complied with. Figure 1 presents, however, a scatterplot of the squared residuals relative to the unstandardized predicted values, which suggests that the assumption of homoscedasticity is being violated. Both the Breusch and Pagan (1979) and the White (1980) tests yielded probability values of less than 0,05 , indicating heteroscedasticity in the sample. In line with the approach recommended by Huber (1967) and White (1980), robust error terms were introduced to deal with this.

The final diagnostic tests involve the calculation of Cook's distance, as the basis for identifying outliers and analysing their leverage (Cook 1977; Montgomery et al. 2012). The calculations reveal that there are outliers present and that some of these observations have leverage. To determine the extent to which the leveraged observations impact parameter estimates and whether the sample is robust, a set of diagnostic tests suggested by Rose (2004) is implemented. While the final dataset includes approximately $98 \%$ of the total quantity of cars exported from Germany for all 4 years measured, this suggested approach involves estimating a model for a sub-sample of the full dataset such that: sample (1) excludes $3 \sigma$ outliers; sample (2) excludes $2 \sigma$ outliers; sample (3) includes only those exports to countries reported as having a high income by the World Bank (2017d); sample (4) includes only those exports to countries reported as having upper middle income by the World Bank (2017e) and; sample (5) includes only those exports to countries reported as having lower middle income by the World Bank (2017f) .

Table 2 Pearson's correlation

\begin{tabular}{llllll}
\hline & Exported quantity $_{\mathrm{ij}}$ & $\mathrm{GDP}_{\mathrm{j}}$ & Distance $_{\mathrm{ij}}$ & Tariff $_{\mathrm{ij}}$ & Logistics $_{\mathrm{j}}$ \\
\hline Exported quantity $_{\mathrm{ij}}$ & 1000 & 0,745 & $-0,334$ & $-0,285$ & 0,765 \\
GDP $_{\mathrm{j}}$ & 0,745 & 1000 & 0,127 & 0,225 & 0,581 \\
Distance $_{\mathrm{ij}}$ & $-0,334$ & 0,127 & 1000 & 0,482 & $-0,241$ \\
Tariff $_{\mathrm{ij}}$ & $-0,285$ & 0,225 & 0,482 & 1000 & $-0,206$ \\
Logistics $_{j}$ & 0,765 & 0,581 & $-0,241$ & $-0,206$ & 1000 \\
\hline
\end{tabular}


Table 3 Variance inflation factors

\begin{tabular}{lllll}
\hline & 2015 & 2014 & 2013 & 2012 \\
\hline GDP $_{j}$ & 1918 & 1877 & 1615 & 2595 \\
Distance & 1381 & 1375 & 0,992 & 1004 \\
Tariff $_{i j}$ & 1481 & 1447 & 1844 & 1222 \\
Logistics $_{j}$ & 1482 & 1976 & 1740 & 2151 \\
\hline
\end{tabular}

As might be expected, the results from these diagnostic tests indicate that excluding outliers reduces the variability of the dataset and increases the explanatory power of the estimated regression model. However, excluding outliers does not impact the coefficients to a very large extent. To split the model based on income level increases the explanatory power of the regression analysis in the case of rich countries (denoted sample (3) in Table 4) and influences some coefficients. Most notably, there is an increase in the impact of GDP and a reduction in the impact of tariffs.

In summary, these diagnostic tests do not yield any categorical evidence of a lack of robustness in the parameter estimates derived from a regression analysis using the full dataset. In any case, since outliers contain important evidence of irregular activities which the data describes, many would argue that they should remain in the dataset analysed (Aggarwal and Yu 2001). Thus, the parameter estimates derived from a regression analysis of the original full dataset remain as the basis for the forecasting model utilised in the ensuing section.

\section{Results}

\section{The forecasting model}

As commonly applied in the forecasting of demand or production (Head and Mayer 2014), a double-logarithmic technique was utilised to convert the final gravity model to constant elasticity in order to facilitate econometric analysis. Applying a confidence interval of $95 \%$, the results from the final gravity model are statistically significant and explain between $85.5 \%$ and $88.5 \%$ of the variability of the export quantities in each year of the sample period. The sample dataset consists of all countries to which Germany (country $i$ ) exported more than 1000 units in the designated year and for which data

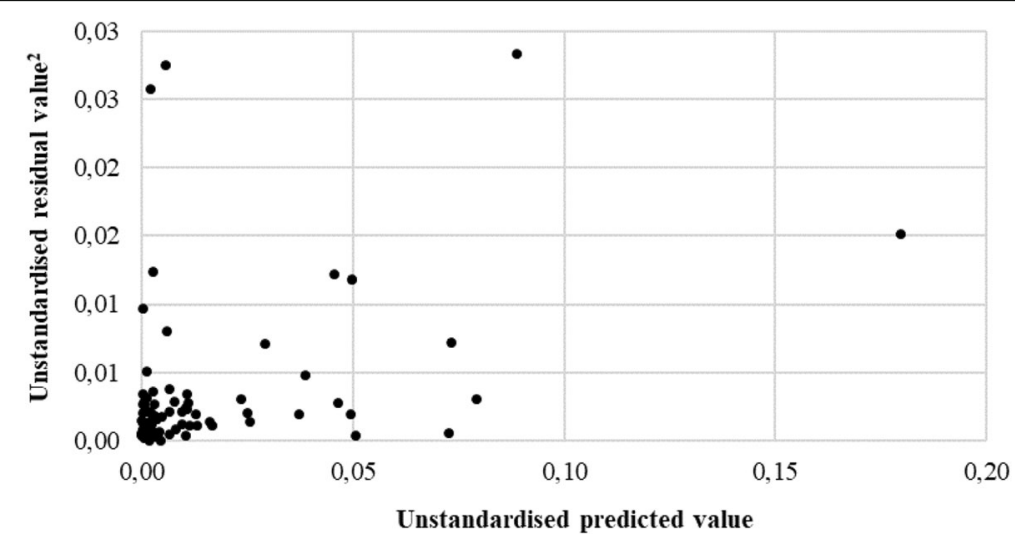

Fig. 1 Scatterplot test for homoscedasticity 
Table 4 Diagnostic tests based on sub-samples

\begin{tabular}{llllll}
\hline & $(1)$ & $(2)$ & $(3)$ & $(4)$ & $(5)$ \\
\hline GDP $_{\mathrm{j}}$ & 0,779 & 0,820 & 0,861 & 0,756 & 0,302 \\
& $(13.67)$ & $(16.40)$ & $(15.65)$ & $(6.25)$ & $(0.95)$ \\
Distance $_{\mathrm{ij}}$ & $-0,356$ & $-0,379$ & $-0,356$ & $-0,767$ & $-0,518$ \\
& $(5.84)$ & $(6.42)$ & $(5.01)$ & $(3.97)$ & $(1.69)$ \\
Tariff & -3938 & -3488 & -2560 & -1809 & -2648 \\
& $(-4.60)$ & $(-5.18)$ & $(1.01)$ & $(-1.99)$ & $(1.21)$ \\
Logistics $_{\text {j }}$ & 1867 & 1810 & 1177 & 3440 & 2742 \\
& $(4.29)$ & $(4.61)$ & $(1.66)$ & $(-3.08)$ & $(-0.78)$ \\
Observations & 83 & 80 & 45 & 25 & 13 \\
- of total export quantity & 0,980 & 0,980 & 0,822 & 0,149 & 0,010 \\
Significance F & 0,000 & 0,000 & 0,000 & 0,000 & 0,466 \\
R Square & 0,877 & 0,908 & 0,937 & 0,793 & 0,331 \\
Adjusted R Square & 0,871 & 0,903 & 0,931 & 0,752 & $-0,004$ \\
\hline
\end{tabular}

Note: t-statistics are displayed in parentheses

were available. Hence, this sample size represents approximately $98 \%$ of the total number of Germany's exported passenger cars in each year. Table 5 presents the consolidated results from the gravity model by year.

The estimated coefficients for the 2015 gravity model were utilised in the forecasting model. Based on the gravity equation defined in Eq. (6), both short-term and long-term forecasts were derived (for 2020 and 2030 respectively) to quantify the effect of Brexit on German car exports to the U.K.

Forecast input values for GDP are based on a report by the Organisation for Economic Cooperation and Development which presented a GDP forecast for a base-case 'No Change' (No Brexit) scenario and then forecasts of how GDP would change with Brexit under different possible future scenarios, expressed as 'optimistic', 'central' and 'pessimistic' (OECD 2016). Forecast input values for the tariff rate were assumed to be: the current 'Most

Table 5 Results from the gravity model

\begin{tabular}{lllll}
\hline & 2015 & 2014 & 2013 & 2012 \\
\hline GDP $_{j}$ & 0,760 & 0,804 & 0,839 & 0,812 \\
& $(12.46)$ & $(14.11)$ & $(15.25)$ & $(12.69)$ \\
Distance & & -015 & $-0,303$ \\
& $-0,369$ & $-0,296$ & $-0,287$ & $(-5.05)$ \\
Tariff & $(-5.86)$ & $(-4.63)$ & $(-4.63)$ & -4039 \\
& -3958 & -3576 & -3799 & $(-7.52)$ \\
Logistics & $(-4.59)$ & $(-5.16)$ & $(-5.53)$ & 1587 \\
& 1988 & 1955 & 1522 & $(3.34)$ \\
Observations & $(4.42)$ & $(4.24)$ & $(3.18)$ & 84 \\
- of total export quantity & 84 & 80 & 83 & 0,975 \\
Significance F & 0,981 & 0,976 & 0,976 & 0,000 \\
R Square & 0,000 & 0,000 & 0,000 & 0,890 \\
Adjusted R Square & 0,862 & 0,879 & 0,879 & 0,885 \\
\hline Note: & 0,855 & 0,873 & 0,873 &
\end{tabular}

Note: t-statistics are displayed in parentheses. All variables are in logarithms and are statistically significant 
Favoured Nation (MFN)' rate in the absence of a Preferential Trade Agreement (PTA) for the 'pessimistic' scenario; the most popular tariff rate in the dataset that was greater than zero for the 'central' scenario and; a tariff rate of zero for the 'optimistic' scenario.

In summary, the specific scenarios tested for 2020 are specified as follows:

No change: A GDP reduction of $0.00 \%$ and a tariff rate of $0.00 \%$ are assumed. This scenario reflects a development whereby the U.K. did not exit the EU. It could also reflect the successful negotiation of a transitional agreement. OECD (2016) suggests that either of these two outcomes will serve to strengthen external perceptions of the EU and provide a stimulus to trade and foreign direct investment in every member state. In fact, the assumptions for GDP growth and tariff rates under this scenario could actually be viewed as rather conservative if the UK's decision to remain aligned to the EU were to facilitate further free trade and investment agreements with non-EU nations.

Central scenario: A GDP reduction of $3.30 \%$ and a tariff rate of $5.00 \%$ are assumed. The tariff rate is meant to reflect a semi-beneficial scenario whereby, for example, the U.K. successfully negotiated a bilateral agreement with the EU. The logic underpinning these forecast values revolves around the greater economic uncertainty that the U.K. would face after leaving the EU, especially during the early years (OECD 2016). Investor and consumer confidence is likely to fall and spending decisions deferred therefore. The potential also exists for a flight of capital out of the country. While the latter means a reduced availability of capital, the former implies the presence of a risk premium which will raise the cost of capital. In addition, since it will take time to develop new trade agreements, the OECD (2016) suggests that the UK will initially have to trade under WTO rules with both EU and third-party nations. Planned changes to immigration policies within the UK and the deterrent effect of a stuttering economy will also lead to reduced GDP, exacerbated by a depreciation in the value of sterling.

For the forecast year of 2030, two additional scenarios are also tested, specified as follows:

Pessimistic scenario: A GDP reduction of $7.70 \%$ and a tariff rate of $9.70 \%$ are assumed. The tariff rate is based on the current MFN rate and the scenario could reflect trade under WTO terms. OECD (2016) forecasts that longer-term structural changes to the U.K. economy would result in lower business investment than would otherwise occur and a continuous decline in capital stock. A predicted reduction in innovation, the skills base and managerial quality also contributes to this longer-term pessimistic scenario, all of which undermines future potential returns on what is expected to become a declining asset base in the U.K.

Optimistic scenario: A GDP reduction of $2.72 \%$ and a tariff rate of $0.00 \%$ are assumed. This reflects a scenario in which the U.K. either remains within the Single Market or where some of the losses outlined in the pessimistic scenario are offset by greater deregulation of the U.K. labour and product markets, as well as by fiscal savings from stopping the net transfer of funds to the EU. Since UK labour and product markets are already highly deregulated and the OECD (2016) predicts UK fiscal savings of only $0.3-0.4 \%$ of GDP, the potential for this offset value is rather minimal.

For each of the forecast scenarios $(f)$, the GDP of country $j$ (the UK), was adjusted in the following manner:

$$
G D P_{f}=s_{t} \times\left(1-x_{f}\right)
$$

where the variables were defined as follows: 
$G D P_{f}$ forecast GDP for country $j$ under scenario $f$;

$s_{t}$ forecast GDP for country $j$ in the absence of Brexit; and.

$x_{f}$ forecast percentage GDP change for country $j$ under scenario $f$.

In the forecasting model, country $i$ denotes variables related to Germany and country $j$ variables relate to the UK. Moreover, the distance in kilometres between London and Berlin is used; the value of 1 was added to the tariff rate; and the quality of logistics in 2016 was applied to all scenarios, no matter year and severity.

Based on Eq. (6) and adjusted to take into account Eq. (8), the forecasting model is defined as:

$$
\begin{aligned}
\ln \left(E X_{i j}\right) & =\alpha+0,760 \ln \left(s_{t} \times\left(1-x_{f}\right)\right)-0,369 \ln \left(D_{i j}\right)-3,958 \ln \left(\text { TARIFF }_{i j}+1\right) \\
& +1,988 \ln \left(\left(\frac{x_{j}}{x_{i}}\right) \times 100\right)+e_{i j}
\end{aligned}
$$

\section{Model outputs}

The results from the forecasts show that if there were to be no Brexit or, alternatively, if a transition deal without changes to the current agreement could be negotiated, Germany is predicted to export 1.3 million passenger cars to the UK in 2020. Nevertheless, if Brexit does occur and a 5\% tariff is applied, this quantity would decrease by $7.73 \%$, representing lost sales volume of approximately 102,000 passenger cars.

The forecast for 2030 was based on three different scenarios. The pessimistic scenario projected that Germany would export $15.39 \%$ less cars to the UK than if no Brexit would occur; the optimistic scenario would lead to $0.92 \%$ less exported cars compared to a scenario in the absence of the Brexit; and the central scenario would lead to a reduction of $9.20 \%$ exported passenger cars from Germany to the UK.

Hence, all Brexit scenarios would lead to lower export quantities of passenger cars from Germany to the UK in terms of number of units, compared to a situation where the UK would have stayed in the EU. Table 6 presents a consolidated view of the forecast outcomes.

In summary, based on a model which includes GDP, distance, tariffs and the quality of logistics - capturing demand factors and logistics-related costs - all Brexit scenarios are estimated to reduce German export quantities compared to a situation where Brexit did not occur.

\section{Conclusions}

The trading relationship between Germany and the UK will inevitably change when the UK leaves the EU. The size of the effects will depend, to a large extent, on the terms

\begin{tabular}{|c|c|c|c|c|}
\hline & 2020 & Impact (+/-) & 2030 & Impact (+/-) \\
\hline \multicolumn{5}{|l|}{ No Brexit } \\
\hline Nothing changes & $1,316,383$ & & $1,431,375$ & \\
\hline \multicolumn{5}{|l|}{ Brexit } \\
\hline Pessimistic scenario & & & $1,211,136$ & $-15,39 \%$ \\
\hline Central scenario & $1,214,595$ & $-7,73 \%$ & $1,299,636$ & $-9,20 \%$ \\
\hline Optimistic scenario & & & $1,418,246$ & $-0,92 \%$ \\
\hline
\end{tabular}

Table 6 Results from the forecasting model 
under which the two countries will trade in the future. The future financial and trade-related uncertainties relating to Brexit will depend, to a large extent, on whether the UK retains access to the Single Market. Assuming that the UK does lose access to the Single Market, the OECD (2016) estimates that the UK's exports will drop by $8 \%$ due to this loss of preferential treatment, not just with the EU but also with other trade partners. The OECD also asserts that supply chains in both the UK and the EU, which have developed over a long time, would disentangle and production costs could increase for both parties (OECD 2016). Similarly, HM Treasury (2016) has calculated that the UK's total trade quantities would decrease by between 17 and $24 \%$ as the result of not having access to the Single Market. However, there have been arguments raised against these relatively pessimistic predictions. For instance, in full expectation of potential supply chain disruption, many organizations and political institutions are developing plans (in some cases jointly) to avoid or surmount whatever difficulties and problems may arise with existing supply chains (Manners-Bell 2017). Given the role played by the 'Quality of Logistics' variable in the final model, this should have a significant impact on model outputs. Similarly, many observers are pointing to the potential benefits to UK competitiveness and GDP that comes from the seemingly inevitable weaker currency that will result from leaving the EU (Dhingra et al. 2016) and this too should also be reflected in the findings derived from the model.

Open Europe (2015) argues that the best case scenario would be for the UK to develop an FTA with the EU. They estimate that the UK GDP would be 1.6\% higher in 2030 under such a scenario compared to if the UK stayed in the EU (Open Europe 2015). Gros (2016) also argues that the negative effect of Brexit on the GDP of the UK would be long-term and that this would lead to a weaker currency which could have a positive impact on export competitiveness, as well as mitigate the financial impact of leaving the Single Market. More pessimistically, HM Treasury (2016) suggests that trade would be lower in many product sectors if the UK were to trade under an FTA with the EU. This is due to an estimated negative impact on production, brought about by an assumed decrease in foreign direct investment into the UK. Open Europe (2015) has developed a 'worst case' scenario where the UK fails to develop a trade deal and loses access to the Single Market. Under such a scenario, they have estimated that the UK GDP would be $2.2 \%$ lower in $2030 \mathrm{com}$ pared to if it had stayed in the EU (Open Europe 2015).

The outcome of the analysis herein is that under all likely Brexit scenarios that have been identified in an extensive review of the literature, the export quantities of German passenger cars to the UK are estimated to decrease. Analysing the estimated parameters associated with the key variables in the model reveals the extent of the expected decrease. The estimated short term impact suggests that Germany could expect to export 7.73\% less cars in 2020 compared to a situation of no Brexit. The long term impact under a pessimistic scenario involves applying the MFN tariff rate and utilising a forecast large reduction in the GDP of the UK. This yields a predicted decrease of $15.39 \%$ in passenger car exports from Germany to the UK in 2030, compared to a scenario of no Brexit. Under a central scenario, which involves applying a $5.00 \%$ tariff and only a moderate forecast reduction in the GDP of the UK, export quantities are forecast to decrease by $9.20 \%$. If the UK were to trade with the EU without tariffs and, in consequence, with only a relatively small reduction in GDP, the export of German passenger cars to the UK is estimated to decrease by $0.92 \%$. Of course, this finding raises the 
question of how German car exporters are going to offset this loss of export value by expanding export volumes in other markets. Similarly, it is interesting to determine what knock-on effects the findings imply for the demand for cars in the UK, particularly with respect to the identification of substitute sources to satisfy this demand. Both issues constitute suitable topics for future research.

The analysis conducted herein finds that the effect of tariffs is substantial in determining model forecasts. This might suggest that representatives of the automotive industry should be lobbying politicians to develop an agreement between the UK and the EU where passenger cars would face low tariffs. Nonetheless, even under a no tariff scenario, German exports of passenger cars to the UK is still forecast to decrease. This is because the expected negative impact on the GDP of the UK will effectively offset the benefits of trading without tariffs. Thus, the forecast input values for the GDP of the UK under each of the tested Brexit scenarios are critical to the forecast outcomes produced by the model. The GDP forecast values utilised in this analysis have been sourced from the OECD (2016) and predict reductions in GDP under all Brexit scenarios compared to the situation of no Brexit. Clearly, such forecasts are subject to error, even to the extent that future GDP values may actually prove to be positive compared to the no Brexit base-case. This points to the fact that it is not the absolute values of the forecasts derived under each Brexit scenario which is critical, but rather the relative outcomes achieved under each scenario, since it is this which should motivate the German government and automotive industry to seek lower tariffs under Brexit in support of its exports to the UK. At the same time, the differential impact of the different scenarios should also inform the actions and decisions of supporting industries such as supply chain planners and the logistics sector, particularly in seeking to avoid any potential disruption to existing supply chains.

Clearly, the analysis reported herein can be applied to other industrial sectors and to other bilateral trades between the UK and other EU member states. There is also great scope for the disaggregation of the results achieved within this work, to analyse the impact under each of the tested Brexit scenarios on the individual segments or even brands which comprise German car exports to the UK. In other words, to take into account the different price elasticities which exist within different passenger car segments or across the four major German brands in the UK market; Volkswagen, BMW, Audi and Mercedes-Benz.

\section{Endnotes}

${ }^{1}$ In 2015, the most important countries of origin for the UK's total imports (in terms of value of all products) were Germany (15.0\%), China (10.0\%), the U.S (9.2\%), the Netherlands (7.5\%) and France (6.1\%) (United Nations 2017a).

${ }^{2}$ In 2015, Germany's biggest export partners for passenger cars were the UK (17.4\%), the U.S (15.9\%), China (7.8\%), France (6.5\%) and Italy (5.5\%) (United Nations 2017a).

${ }^{3}$ In 2015 , Germany was the largest source of passenger car imports into the UK in volume terms $(39.0 \%)$, followed by Spain $(12.3 \%)$. Germany was also the largest source of UK passenger car imports in terms of value (48.1\%), followed by Belgium (13.3\%), Spain (10.2\%), France (4.7\%) and Japan (4.1\%) (United Nations 2017a).

\footnotetext{
${ }^{4}$ Audi is a subsidiary of Volkswagen.
} 
${ }^{5} \mathrm{~A}$ full list of importing nations (country $\mathrm{j}$ ) which were included in, and excluded from, the sample dataset and the quantities represented of the total export quantity is available from the corresponding author.

${ }^{6}$ See United Nations Statistics $(2010,2013)$ for a detailed descriptions of the data sources, methodology and limitations of the Comtrade database.

${ }^{7} \mathrm{GDP}$ at purchaser's prices is the "sum of gross value added by all resident producers in the economy plus any product taxes and minus any subsidies not included in the value of the products. It is calculated without making deductions for depreciation of fabricated assets or for depletion and degradation of natural resources. Data are in current U.S. dollars. Dollar figures for GDP are converted from domestic currencies using single year official exchange rates. For a few countries where the official exchange rate does not reflect the rate effectively applied to actual foreign exchange transactions, an alternative conversion factor is used" (World Bank 2017c).

${ }^{8}$ Where sea transport is assumed and distance is measured on a port-to-port basis, there is an implicit assumption that in estimating a model based on the global trade in cars, road distances are relatively trivial compared to distances at sea and that sea distances are, therefore, quite highly correlated with total transport distance where shipping is employed. While this supports the likely unbiasedness of the coefficient which is estimated for this variable, it does not negate using a more appropriate input value for distance when applying the model to an individual bilateral trade. Thus, in the later application of this estimated gravity model to the specific trade in cars from Germany to the UK, the distance between capital cities is utilized as a more realistic input value for distance, even though shipping is the primary mode of carriage.

\section{Abbreviations}

BMW: Bayerische Motoren Werke; CIA: Central Intelligence Agency; EEA: European Economic Area; EFTA: European Free Trade Association; EU: European Union; FTA: Free Trade Agreement; GBP: Great British Pound; GDP: Gross Domestic Product; HM: Her Majesty; HS: Harmonized Commodity Description and Coding System; LPI: Logistics Performance Index; LSCI: Liner Shipping Connectivity Index; MFN: Most Favoured Nation; OECD: Organisation for Economic Cooperation and Development; OLS: Ordinary Least Squares; PTA: Preferential Trade Agreement; PwC: Price Waterhouse Cooper; SMMT: Society of Motor Manufacturers and Traders; UK: United Kingdom; UN: United Nations; VDA: Verband der Automobilindustrie; VIF: Variance Inflation Factor; WTO: World Trade Organization

\section{Acknowledgements}

The authors would like to express their gratitude to three anonymous referees that provided extremely helpful comments on an earlier draft of this paper. Also, thanks are due to Prof. Mike Lai for expediting the publication process in his role as Editor-in-Chief of the journal.

Funding

The research reported within the paper was not supported by any form of external funding.

Availability of data and materials

The datasets used and/or analysed during the current study are available from the corresponding author on reasonable request.

Authors' contributions

Each of the co-authors contributed to all aspects of the paper. All authors read and approved the final manuscript.

Competing interests

The authors declare that they have no competing interests. 
Received: 10 August 2018 Accepted: 15 October 2018

Published online: 01 November 2018

\section{References}

Abrams R (1980) International trade flows under flexible exchange rates. Federal Reserve Bank of Kansas City. Econ Rev 65(3): $3-10$

ACEA (2016) The Automobile Industry Pocket Guide 2016-2017. In: European Automobile Manufacturers Association http:// www.acea.be/uploads/publications/ACEA_Pocket_Guide_2016_2017.pdf Accessed 1 Mar 2017

Aggarwal C, Yu P (2001) Outlier detection for high dimensional data. ACM SIGMOD Rec 30(2):37-46

Aitken N (1973) The effect of the EEC and EFTA on European trade: a temporal cross-section analysis. Am Econ Rev 63(5): $881-892$

Anderson J (1979) A Theoretical Foundation for the gravity equation. Am Econ Rev 69(1):106-116

Anderson J (2011) The gravity model. Ann Rev Econ 3(1):133-160

Anderson J, van Wincoop E (2003) Gravity with gravitas: a solution to the border puzzle. Am Econ Rev 93(1):170-192

Anderson J, van Wincoop E (2004) Trade Costs. J Econ Lit 42(3):691-751

Baier S, Bergstrand J (2001) The growth of world trade: tariffs, transport costs, and income similarity. J Int Econ 53(1):1-27

Baier S, Bergstrand J (2007) Do free trade agreements actually increase Members' International trade? I Int Econ 71(1):72-95

Baker A, Ali R, Thrasher A (2016) Impact of BREXIT on UK gene and Cell therapy: the need for continued Pan-European collaboration. Hum Gene Ther 27(9):653-655

Balassa B (1967) Trade creation and trade diversion in the European common market. Econ J 77(305):1

Bayoumi T, Eichengreen B (1995) Is regionalism simply a diversion? Evidence from the evolution of the EC and EFTA. IMF Working Pap 95(109):1

Bergstrand J (1985) The gravity equation in international trade: some microeconomic foundations and empirical evidence. Rev Econ Stat 67(3):474-481

Bergstrand J (1990) The Heckscher-Ohlin-Samuelson model, the Linder hypothesis and the determinants of bilateral intraindustry trade. Econ J 100(403):1216-1229

Biscop S (2016) All or nothing? The EU global strategy and defence policy after the Brexit. Contemp Sec Pol 37(3):431-445

Bougheas S, Demetriades P, Morgenroth E (1999) Infrastructure, transport costs and trade. J Int Econ 47(1):169-189

Boulanger P, Philippidis G (2015) The end of a romance? A note on the quantitative impacts of a 'Brexit' from the EU. J Agric Econ 66(3):832-842

Boyes S, Elliott M (2016) Brexit: the marine governance horrendogram just got more horrendous! Mar Pollut Bull 111(1-2):41-44

Brada J, Mendez J (1985) Economic integration among developed, developing and centrally planned economies: a comparative analysis. Rev Econ Stat 67(4):549

Breusch T, Pagan A (1979) A simple test for heteroscedasticity and random coefficient variation. Econometrica 47(5):1287-1294

Butler G, Jensen M, Snaith H (2016) 'Slow change may pull us apart': debating a British exit from the European Union. J Eur Publ Pol 23(9):1278-1284

Campbell P (2016) UK car industry fears effects of Brexit tariffs on supply chain. In: The Financial Times https://www.ft.com/ content/c397f174-9205-11e6-a72e-b428cb934b78 Accessed 8 Feb 2017

Caporale GM, Rault C, Sova R, Sova A (2009) On the bilateral trade effects of free trade agreements between the EU-15 and the CEEC-4 countries. Rev World Econ 145(2):189-206

Carrere C (2006) Revisiting the effects of regional trade agreements on trade flows with proper specification of the gravity model. Eur Econ Rev 50(2):223-247

Castle P (2017) U.K. Initiates 'Brexit' and Wades Into a Thorny Thicket. In: The New York Times https://www.nytimes.com/ 2017/03/29/world/europe/brexit-uk-eu-article-50.html Accessed 8 Feb 2017

Chalmers D (2016) Alternatives to EU membership and the rational imagination. Polit Q 87(2):269-279

Chen N (2004) Intra-national versus international trade in the European Union: why do national borders matter? J Int Econ 63(1):93-118

Chi T, Kilduff P (2010) An empirical investigation of the determinants and shifting patterns of US apparel imports using a gravity model framework. J Fashion Mark Manag Int J 14(3):501-520

CIA (2017) Library. In: CIA https://www.cia.gov/library/publications/the-world-factbook/fields/2098.html Accessed 24 Feb 2017

Cipollina M, Salvatici L (2010) Reciprocal trade agreements in gravity models: a meta-analysis. Rev Int Econ 18(1):63-80

Cook R (1977) Detection of influential observation in linear regression. Technometrics 19(1):15-18

Dhingra S, Ottaviano G, Sampson T, Van Reenen J (2016) The impact of Brexit on foreign investment in the UK. Centre for Economic Performance, London School of Economics, BREXIT, p 24 http://www.kenwitsconsultancy.co.uk/wp-content/ uploads/2016/09/BREXIT-2016-Policy-Analysis-from-the-Centre-for-Economic-Performance.pdf\#page=40, (Viewed 05/04/ 18)

Disdier A, Head K (2008) The puzzling persistence of the distance effect on bilateral trade. Rev Econ Stat 90(1):37-48

Eaton J, Kortum S (2002) Technology, geography, and trade. Econometrica 70(5):1741-1779

Economist (2016) Economic integration and the "four freedoms". In: De Economist http://www.economist.com/news/finance-andeconomics/21711327-why-free-movement-labour-essential-europes-economic-project-economic Accessed 24 April 2017

Economist (2017) Why the "WTO option" for Brexit will prove tricky. In: De Economist http://www.economist.com/blogs/ economist-explains/2017/01/economist-explains-4 Accessed 10 Feb 2017

Eichengreen B, Irwin D (1995) Trade blocs, currency blocs and the reorientation of world trade in the 1930s. J Int Econ 38(12): $1-24$

Emerson M (2016) Which model for Brexit? In: CEPS Special Report https://www.ceps.eu/system/files/ SR147\%20ME\%20Which\%20model\%20for\%20Brexit.pdf Accessed 6 Feb 2017

European Commission (2017) Database - Eurostat. In: European Commission http://ec.europa.eu/eurostat/data/database Accessed 17 April 2017

European Union. (2017). About the EU European Union. Available at: https://europa.eu/european-union/about-eu/countries_ en Accessed 25 April 2017 
European Union Committee (2016) Brexit: the options for trade. In: European Union Committee https://www.publications. parliament.uk/pa/ld201617//dselect/ldeucom/72/72.pdf Accessed 10 Feb 2017

Evenett S, Keller W (2002) On theories explaining the success of the gravity equation. J Polit Econ 110(2):281-316

Feenstra R (2002) Border effects and the gravity equation: consistent methods for estimation. Scott J Pol Econ 49(5):491-506

Frankel J, Stein E, Wei S (1995) Trading blocs and the Americas: the natural, the unnatural, and the super-natural. J Dev Econ 47(1):61-95

Glencross A (2015) Why a British referendum on EU membership will not solve the Europe question. Int Aff 91(2):303-317

Goodwin M, Heath O (2016) The 2016 referendum, Brexit and the left behind: an aggregate-level analysis of the result. Polit Q 87(3):323-332

Google Maps (2017) Google Maps. In: Google Maps https://www.google.se/maps Accessed 17 April 2017

Gordon M (2016) Brexit: a challenge for the UK constitution, of the UK constitution? Eur Const Law Rev 12(03):409-444

Grant W (2016) The challenges facing UK farmers from Brexit. EuroChoices 15(2):11-16

Greene W (2003) Econometric Analysis, 5th edn. Prentice Hall, Upper Saddle River

Gros D (2016) The Not-So-High Costs of Brexit. In: Project Syndicate https://www.project-syndicate.org/commentary/ overblown-costs-of-brexit-by-daniel-gros-2016-09 Accessed 17 Feb 2017

Havrylyshyn O, Pritchett L (1991) European trade patterns after the transition. In: World Bank Working Paper WPS. World Bank, Washington, DC, p 748

Head K, Mayer T (2014) Gravity equations: workhorse, toolkit, and cookbook. In: Gopinath G, Helpman E, Rogoff K (eds) Handbook of International Economics, vol 4. Elsevier, Amsterdam, pp 131-195

HM Treasury (2016) HM Treasury analysis: the long-term economic impact of EU membership and the alternatives. In: HM Treasury https://www.gov.uk/government/uploads/system/uploads/attachment_data/file/517415/treasury_analysis_ economic_impact_of_eu_membership_web.pdf Accessed 10 Feb 2017

Hobolt S (2016) The Brexit vote: a divided nation, a divided continent. J Eur Publ Pol 23(9):1259-1277

House of Commons (2013) Leaving the EU. Res Pap 13/42. In: UK Parliament http://researchbriefings.parliament.uk/ ResearchBriefing/Summary/RP13-42 Accessed 10 Feb 2017

Huber PJ (1967) The behavior of maximum likelihood estimates under nonstandard conditions. In: Proceedings of the Fifth Berkeley Symposium on Mathematical Statistics and Probability, vol 1. Berkeley, University of California Press, pp 221-233

Hummels D (2001) Toward a Geography of Trade Costs. In: SSRN Electronic Journal, GTAP Working Papers, Paper, p 17

Hunt A, Wheeler B (2017) Brexit: All you need to know about the UK leaving the EU. In: BBC News http://www.bbc.com/ news/uk-politics-32810887 Accessed 6 Feb 2017

Jensen M, Snaith H (2016) When politics prevails: the political economy of a Brexit. J Eur Public Pol 23(9):1302-1310

Kepaptsoglou K, Karlaftis M, Tsamboulas D (2010) The gravity model specification for modeling international trade flows and free trade agreement effects: a 10-year review of empirical studies. Open Econ J 3(1):1-13

Kroll D, Leuffen D (2016) Ties that bind, can also strangle: the Brexit threat and the hardships of reforming the EU. J Eur Public Pol 23(9):1311-1320

Lavergne M (2004) The long and short of the Canada-US free trade agreement. Am Econ Rev 94(4):870-895

Lazowski A (2016) Unilateral withdrawal from the EU: realistic scenario or a folly? J Eur Public Pol 23(9):1294-1301

Liang J, Pan W, Yang Z (2004) Characterization-based Q-Q plots for testing multinormality. Stat Prob Lett 70(3):183-190

Linder S (1961) An essay on trade and transformation, 1st edn. John Wiley, New York

Linnemann H (1966) An econometric study of international trade flows, 1st edn. North Holland Publishing Company

Manners-Bell J (2017) Supply chain risk management: understanding emerging threats to global supply chains. Kogan Page Publishers

Marinetraffic (2017) MarineTraffic Voyage planner - Distance calculator - Route finder. In: Marinetraffic https:/www. marinetraffic.com/en/voyage-planner Accessed 11 April 2017

Martin W, Pham C (2015) Estimating the gravity model when zero trade flows are frequent and economically determined. In: World Bank Group http://documents.worldbank.org/curated/en/695631467998785933/pdf/WPS7308.pdf Accessed 25 April 2017

Matthews A (2016) The potential implications of a Brexit for future EU Agri-food policies. EuroChoices 15(2):17-23

McCallum J (1995) National Borders Matter: Canada-U.S. Regional Trade Patterns. Am Econ Rev 85(3):615-623

Mclvor RT, Humphreys PK, McAleer WE (1998) European car makers and their suppliers: changes at the interface. Eur Bus Rev 98(2):87-99

Menon A, Salter J (2016a) Brexit: initial reflections. Int Aff 92(6):1297-1318

Menon A, Salter J (2016b) Britain's influence in the EU. Natl Inst Econ Rev 236(1):7-13

Monaghan A (2016) UK car industry risks 'death by a thousand cuts' after Brexit vote. In: The Guardian https://www. theguardian.com/business/2016/nov/03/uk-car-industry-risks-death-by-thousand-cuts-brexit-vote Accessed 7 Mar 2017

Montgomery D, Peck E, Vining G (2012) Introduction to linear regression analysis, 5th edn. John Wiley and Sons, Inc, Hoboken

O'Brien R (2007) A caution regarding rules of thumb for variance inflation factors. Qual Quant 41(5):673-690

OECD (2016) The economic consequences of Brexit: a taxing decision. In: OECD http://www.oecd-library.org/docserver/ download/5jm0lsvdkf6k-en.pdf?expires=1486712893\&id=id\&accname=guest\&checksum = E10E1D42F00E6D90145FBB1379868519 Accessed 10 Feb 2017

O'Grady S (2016) Brexit latest: Tariffs on UK car exports to Europe would be 'disastrous' for jobs says Jaguar Land Rover boss. In: The Independent http://www.independent.co.uk/news/business/news/brexit-latest-tariffs-on-uk-car-exports-to-europewould-be-disastrous-for-jobs-says-jaguar-land-a7334991.html Accessed 17 Feb 2017

OICA. (2017). 2016 Production Statistics. [dataset] OICA. Available at: http://www.oica.net/category/production-statistics/ Accessed 17 April 2017

Open Europe (2015). What if..? The consequences, challenges and opportunities facing Britain outside the EU. Open Europe. Available at: http://openeurope.org.uk/intelligence/britain-and-the-eu/what-if-there-were-a-brexit/ Accessed 10 Feb 2017

Parker G, Barker A (2017) Theresa may warns UK will walk away from 'bad deal'. In: The Financial Times https://www.ft.com/ content/c3741ca2-dcc6-11e6-86ac-f253db7791c6 Accessed 10 Feb 2017

Prism (2017) Regional Data and Tools. In: Prism http://sdd.spc.int/en/stats-by-topic/population-statistics Accessed 6 April 2017 
PwC (2016) Leaving the EU: Implications for the UK economy. In: PwC http://www.pwc.co.uk/economic-services/assets/ leaving-the-eu-implications-for-the-uk-economy.pdf Accessed 7 March 2017

Rose A (2004) Do we really know that the WTO increases trade? Am Econ Rev 94(1):98-114

Santos Silva J, Tenreyro S (2006) The log of gravity. Rev Econ Stat 88(4):641-658

Simón L (2015) Britain, the European Union and the future of Europe: a geostrategic perspective. RUSI Journal 160(5):16-23 Smarzynska B (2001) Does relative location matter for bilateral trade flows? An extension of the gravity model. J Econ Integr 16(3):379-398

SMMT (2017) SMMT Motor Industry Facts 2016. In: The Society of Motor Manufacturers and Traders (SMMT) https://www. smmt.co.uk/wp-content/uploads/sites/2/SMMT-Motor-Industry-Facts-2016_v2-1.pdf Accessed 1 Mar 2017

Song C (2016) Understanding the aftermath of Brexit: implications for the pharmaceutical industry. Pharm Med 30(5):253-256

Statista (2017) Vehicles \& Road Traffic. [online] Statista. https:/www.statista.com/markets/419/topic/487/vehicles-road-traffic/ Accessed 20 Oct 2018

Swinbank A (2016) Brexit or Bremain? Future options for UK agricultural policy and the CAP. EuroChoices 15(2):5-10

Thielemann E, Schade D (2016) Buying into myths: free movement of people and immigration. Polit Q 87(2):139-147

Thomas R, Oliver N (1991) Components supplier patterns in the UK motor industry. Omega 19(6):609-616

Tinbergen J (1962) Shaping the world economy, 1st edn. Twentieth Century Fund, New York

United Nations (2017a) UN Comtrade Database. In: United Nations http://comtrade.un.org/data/ Accessed 22 Feb 2017

United Nations (2017b) Department of Economic and Social Affairs. In: United Nations https://esa.un.org/unpd/wpp/ Download/Standard/Population/ Accessed 6 April 2017

United Nations Statistics (2010) International Merchandise Trade Statistics. In: United Nations Statistics https://unstats.un.org/ unsd/trade/eg-imts/IMTS\%202010\%20(English).pdf Accessed 25 April 2017

United Nations Statistics (2013) International Merchandise Trade Statistics: Compilers Manual, Revision 1. In: United Nations Statistics https://unstats.un.org/unsd/trade/publications/seriesf_87Rev1_e_cover.pdf Accessed 25 April 2017

United Nations Statistics (2017a) Subcategories do not add up to higher level codes. In: United Nations Statistics https:/unstats. un.org/unsd/tradekb/Knowledgebase/50094/Subcategories-do-not-add-up-to-higher-level-codes Accessed 25 April 2017

United Nations Statistics (2017b) Bilateral asymmetries. In: United Nations Statistics https://unstats.un.org/unsd/tradekb/ Knowledgebase/50657/Bilateral-asymmetries Accessed 25 April 2017

Vasilopoulou S (2016) UK Euroscepticism and the Brexit referendum. Polit Q 87(2):219-227

VDA (2017) Annu Rep 2016. In: Association of the German Automotive Industry https://www.vda.de/en/services/Publications/ annual-report-2016.html Accessed 1 Mar 2017

Wegman E (1990) Hyperdimensional data analysis using parallel coordinates. J Am Stat Assoc 85(411):664-675

White H (1980) A Heteroskedasticity-consistent covariance matrix estimator and a direct test for Heteroskedasticity. Econometrica 48(4):817

World Bank (2014) LPI Methodology. Trade logistics in the global economy. In: World Bank https://wb-lpi-media.s3. amazonaws.com/LPI\%20Methodology.pdf Accessed 17 April 2017

World Bank (2017a) World Development Indicators. In: World Bank http://databank.worldbank.org/data/reports.aspx?Code=NY. GDP.MKTP.KD.ZG\&id=1ff4a498\&report_name=Popular-Indicators\&populartype=series\&ispopular=y Accessed 12 April 2017

World Bank. (2017b). Logistics Performance Index. [dataset] World Bank. Available at: https://lpi.worldbank.org/ Accessed 17 April 2017

World Bank (2017c) GDP (current US\$). In: World Bank http://data.worldbank.org/indicator/NY.GDP.MKTP.CD Accessed 12 April 2017

World Bank (2017d) High income. In: World Bank http://data.worldbank.org/income-level/high-income Accessed 12 April 2017

World Bank (2017e) Upper middle income. In: World Bank http://data.worldbank.org/income-level/upper-middle-income Accessed 12 April 2017

World Bank (2017f) Lower middle income. In: World Bank http://data.worldbank.org/income-level/lower-middle-income Accessed 12 April 2017

World Trade Organization (2017a) Principles of the trading system. In: World Trade Organization https://www.wto.org/ english/thewto_e/whatis_e/tif_e/fact2_e.htm Accessed 23 Feb 2017

World Trade Organization (2017b) Tariff download facility. In: World Trade Organization http://tariffdata.wto.org/ Accessed 6 April 2017

Yamarik S, Ghosh S (2005) A sensitivity analysis of the gravity model. Int Trade J 19(1):83-126

\section{Submit your manuscript to a SpringerOpen ${ }^{\circ}$ journal and benefit from:}

- Convenient online submission

- Rigorous peer review

- Open access: articles freely available online

- High visibility within the field

- Retaining the copyright to your article

Submit your next manuscript at $\boldsymbol{\Delta}$ springeropen.com 